\title{
Mass Rapid Transit Operation and Maintenance Cost Calculation Model
}

\author{
Rahmat Nurcahyo (D), F. Farizal, Bimo M. I. Arifianto, and Muhammad Habiburrahman \\ Industrial Engineering Department, Universitas Indonesia, Depok 16424, Indonesia \\ Correspondence should be addressed to Rahmat Nurcahyo; rahmat@eng.ui.ac.id
}

Received 19 June 2019; Revised 30 September 2019; Accepted 10 October 2019; Published 17 February 2020

Academic Editor: Rocío de Oña

Copyright (C) 2020 Rahmat Nurcahyo et al. This is an open access article distributed under the Creative Commons Attribution License, which permits unrestricted use, distribution, and reproduction in any medium, provided the original work is properly cited.

\begin{abstract}
Mass rapid transit (MRT) is an efficient transportation mode that is urgently needed by a growing city such as Jakarta, Indonesia. However, limited research has attempted to evaluate the system's current performance through a comprehensive, unit-based calculation of the costs of MRT operation and maintenance. This research aimed to develop a system for calculating and comparing MRT operation and maintenance costs per kilometer per year. The cost model has three components, namely, capital, operation cost, and maintenance cost, which are, respectively, calculated based on their percentage toward total cost. The cost model calculation determined that Jakarta MRT operation and maintenance costs total USD 8.44 million per kilometer per year. This result was compared to other countries' MRT operations.
\end{abstract}

\section{Introduction}

Jakarta, the capital of the Republic of Indonesia, is the largest metropolitan area in Southeast Asia [1], and as Indonesia's largest economic center, its population increases from 10 million to 12 million people during working days as people commute into the city proper for work, school, and other activities [2]. Jakarta is currently faced with severe transportation problems: road ratios are less than seven percent; there are growing rates of vehicle ownership and poor public transport facilities; and more than 90 percent of available modes of transportation are road based [2].

One strategy used to address such challenges is an MRT network, which carries passengers faster and safer than other rail systems, while simultaneously reducing environmental pollution from road vehicles [3]. MRTs can be linked with other modes of mass transport (buses and trains) to comprehensively serve metropolitan area commuters using an integrated smartcard ticketing system [4]. Therefore, railbased public transport has become a critical element of urban infrastructures and accordingly has become a focus of increasing attention in research and practice as a solution for social problems accruing from urbanization, traffic congestion, and safety, as well as global warming by $\mathrm{CO}_{2}$ emissions in both developed and developing countries [5].

In recent years, urban railway construction in Indonesia has increased rapidly, particularly in Jakarta [6]. Groundbreaking for the city's MRT began in 2013; the city is currently constructing a north-south line that will link Kampung Bandan (in North Jakarta) to Lebak Bulus (South Jakarta); and an east-west line is targeted for completion from 2024 to 2027 [7]. However, the construction of an MRT requires a very great investment along with large annual operating and maintenance costs [8], which have become a huge burden on government spending. Since MRTs are public welfare facilities, they bring revenue from passenger ticket sales, nonbusiness rail, and government subsidies. Nonetheless, MRTs in cities worldwide rely on government subsidies and supports to maintain operations [9]. Therefore, how to control operating costs has become an important topic of investigation in transportation studies [10].

The objective of this study is to develop a calculation of MRT operation and maintenance (OM) costs per kilometer, which will first be used to determine the overall annual costs of the Jakarta MRT and then applied to calculate transit system costs in Bangkok and Delhi for comparative 
purposes. Comparing Jakarta's MRT operation and maintenance costs with those of other systems can aid in determining the reasonability of spending or reducing wasteful expenditures, as well as providing a basis for researchers and analysts in other urban areas to develop similar models for investigating methods to evaluate and control transport costs. Another benefit of this research is to calculate ticket prices by considering cost recovery along with government subsidies and willingness to pay from passengers.

1.1. Literature Review. An MRT is an urban rail-based mode of transportation that provides a regular and sustainable public service. Therefore, it is essential for the efficient functioning and quality of life in big cities [8]. MRT systems have the highest performance of capacity, speed, and reliability among all other transportation modes, and it has its own path that is completely separated from other modes of transport [11]. An effective MRT system has the ability to influence the shape of the city and contribute to the growth of an area [12].

Researchers have mainly concluded that MRT operating costs encompass the broad categories of main business costs, business taxes and surcharges, sales charges, management fees, and depreciation [9, 13-15]. The main business costs include wages, welfare, the cost of electricity, and vehicle repairs. In addition, in particular circumstances, track and access charges are also considered as elements of operating costs $[16,17]$.

Like other forms of rail transport, fares are charged to passengers of the Jakarta MRT in accordance with Article 146 of Republik Indonesia Regulation No. 72/2009 on traffic and rail, which published its technical implementation of fare determination on Minister of Transportation Regulation No. 69/2014. Under the regulation, four cost components can be classified as part of MRT operation and maintenance costs: (a) capital costs, including the depreciation of fixed assets railway facilities and capital and lease interest; (b) operating costs, comprising "direct fixed costs" (infrastructure, insurance, and railway staff payment), "direct variable costs" (fuel, electricity, clean water, train cleaning, customer service, train security, daily wash facilities, fumigation, pest control, lubricant, and work allowance), "indirect fixed costs" (salaries and rail operation allowances for noncrew members, office expenses, corporate taxes, licenses and certifications, and passenger services at the stations), and "indirect variable costs" (marketing costs, research and development, and human resource development); (c) maintenance costs for trains, electric rails, hydraulic and electric locomotives, and generators; and (d) profits, which are an addition of 10 percent of the total principal costs for the sustainability of the company [18].

\section{Methods}

This research was completed in three stages, the first of which was the development of an MRT operation and maintenance cost model to identify the required data based on a detailed study of theoretical and empirical literature and related Indonesian government regulations. The second stage encompassed the data collection and processing using the predetermined model to obtain the total cost of operation and maintenance per kilometer. The final stage entailed the comparison of the operation and maintenance costs per kilometer per year with various operators.

2.1. Stage 1: MRT Operation and Maintenance Cost Model Development. There are several previous studies related to OM cost for MRT. The mapping of OM cost for MRT based on previous researches is shown in Table 1.

In this study, we use all the fourteen cost components from previous studies.

(1) Depreciation of railway assets: the imposition of charges upon the usage of assets during its economic lifespan [19].

(2) Railway staff costs: the railway staff are those employees directly related to the operation of the MRT; in this case, the machinist and operation control center staff:

$$
\begin{aligned}
\text { wage }\left(\frac{\text { IDR }}{\text { Year }}\right)= & \text { monthly wages }(\text { IDR }) \times \text { total employee } \\
& \times \text { per year. }
\end{aligned}
$$

(3) Infrastructure costs: infrastructure costs which include the cost of track and station facility usage that consist of infrastructure depreciation cost and infrastructure maintenance cost:

$$
\begin{aligned}
& \text { infrastucture maintenance cost }\left(\frac{\mathrm{IDR}}{\text { Year }}\right)=\frac{\text { total LCC }(\text { IDR })}{\text { economic year }(\text { year })}, \\
& \text { infrastucture depreciation cost }\left(\frac{\text { IDR }}{\text { Year }}\right)=\frac{\text { value (IDR) - salvage value (IDR) }}{\text { economic year }(\text { year })} .
\end{aligned}
$$

(4) Insurance costs: insurance costs for railway assets with the following formula:

insurance $\left(\frac{\mathrm{IDR}}{\text { Year }}\right)=$ asset value $(\mathrm{IDR}) \times \operatorname{Premi}(/$ year $)$. 
TABLE 1: Mapping of OM cost component.

\begin{tabular}{|c|c|c|c|c|c|}
\hline \multirow{2}{*}{ Cost component } & \multicolumn{5}{|c|}{ Researchers } \\
\hline & Gattuso and Restuccia [16] & Li and Toda [15] & Liang and Liu [9] & Shang and Zhang [13] & Wang et al. [3] \\
\hline Depreciation of railway assets & $\mathrm{x}$ & $\mathrm{x}$ & $\mathrm{x}$ & $\mathrm{x}$ & \\
\hline Railway staff & $\mathrm{x}$ & $\mathrm{x}$ & $\mathrm{x}$ & $\mathrm{x}$ & $\mathrm{x}$ \\
\hline Infrastructure & $\mathrm{x}$ & $\mathrm{x}$ & & $\mathrm{x}$ & \\
\hline Insurance & & & & $\mathrm{x}$ & \\
\hline Electricity & $\mathrm{x}$ & $\mathrm{x}$ & $\mathrm{x}$ & $\mathrm{x}$ & \\
\hline Security & $\mathrm{x}$ & & & $\mathrm{x}$ & \\
\hline Train cleaning facilities & $\mathrm{x}$ & & & $\mathrm{x}$ & $\mathrm{x}$ \\
\hline Employment & $\mathrm{x}$ & $\mathrm{x}$ & $\mathrm{x}$ & $\mathrm{x}$ & \\
\hline Office expenses & & & $\mathrm{x}$ & $\mathrm{x}$ & \\
\hline License and certification & & & & & \\
\hline Passenger service & $\mathrm{x}$ & $\mathrm{x}$ & $\mathrm{x}$ & $\mathrm{x}$ & $\mathrm{x}$ \\
\hline Marketing & & $\mathrm{x}$ & $\mathrm{x}$ & $\mathrm{x}$ & \\
\hline Human resource development & & & $\mathrm{x}$ & $\mathrm{x}$ & \\
\hline Maintenance & $\mathrm{x}$ & $\mathrm{x}$ & $\mathrm{x}$ & $\mathrm{x}$ & \\
\hline
\end{tabular}

(5) Electricity costs: electrical substation and power flow over the network that serves to transmit electrical power from the source to electric train:

$$
\begin{aligned}
\operatorname{OCH}\left(\frac{\mathrm{IDR}}{\text { Year }}\right)= & \operatorname{std} \text { power }\left(\frac{\mathrm{KWh}}{\mathrm{km}}\right) \times \operatorname{tariff}\left(\frac{\mathrm{IDR}}{\mathrm{KWh}}\right) \\
& \times \operatorname{distance}\left(\frac{\mathrm{km}}{\text { year }}\right) .
\end{aligned}
$$

(6) Train facilities cleaning cost: the cost of the trains to be cleaned daily:

(7) Security costs: the cost of the security in the station and inside the train:

(8) Employment cost: office employees salary:

(9) Office expenses: depreciation costs of office building, office maintenance, office administrators, the cost of electricity, water, telephone, and so on:

(10) Licenses and certificates: the confirmation given by a professional organization to a company that indicates the ability to perform a specific job or task:

(11) Passenger services: cost for passenger service at the station:

(12) Marketing costs: marketing at stations, such as flyers, brochures, souvenirs, advertising, or promotions:

(13) Human resource development costs:

(14) Maintenance cost component: the repair and maintenance cost of the assets which are calculated based on total life cycle cost and economic year:

$$
\text { maintenance cost }\left(\frac{\text { IDR }}{\text { year }}\right)=\frac{\text { total life cycle cost }(\text { IDR })}{\text { economic year }(\text { year })} \text {. }
$$

For the purposes of the MRToperation and maintenance cost model of this research, we group the fourteen cost components into three groups such as capital cost, operation cost, and maintenance cost as presented in Table 2 .

Capital cost is calculated by depreciation of railway assets, since Jakarta MRT receives capital from government to purchase land and to build all the required infrastructure and facilities.

Operation costs comprise four subcomponents: direct fixed costs; direct variable costs; indirect fixed costs; and indirect variable costs. The "direct fixed costs" subcomponent is calculated based on railway staff costs, infrastructure costs, and insurance costs. The "direct variable costs" subcomponent is calculated based on electricity costs, train facilities cleaning costs, and security costs. The "indirect fixed cost" subcomponent is calculated based on employment cost, office expenses, license and certification costs, and passenger service in the station costs. The "indirect variable cost" subcomponent is calculated based on marketing and human resource development costs.

Maintenance cost component is the repair and maintenance cost of the electrical train.

2.2. Stage 2: MRT Operation and Maintenance Costs' Calculation. Based on the MRT operation and maintenance cost model of this research, the calculation for Jakarta MRT case is as follows:

Capital cost: depreciation of railway assets $=$ IDR $1,216,093$ million

Operation costs $=$ direct fixed costs + direct variable costs + indirect fixed costs + indirect variable costs.

Direct fixed cost $=$ railway staff $\cos t+$ infrastructure cost + insurance costs.

Railway staff cost: train driver + operation control center $($ OCC $)$ staff $=($ IDR $9,187,823 \times 32$ train driver $\times 14$ month $)+($ IDR $4,900,172 \times 14$ staff $\times 14$ month) $=$ IDR 4,116,140,000 + IDR 960,430,000 = IDR 5,076.57 million/year.

Infrastructure cost: infrastructure maintenance cost+ infrastructure depreciation $\operatorname{cost}=($ cost of signaling 
TABLE 2: MRT operation and maintenance cost groups and their components.

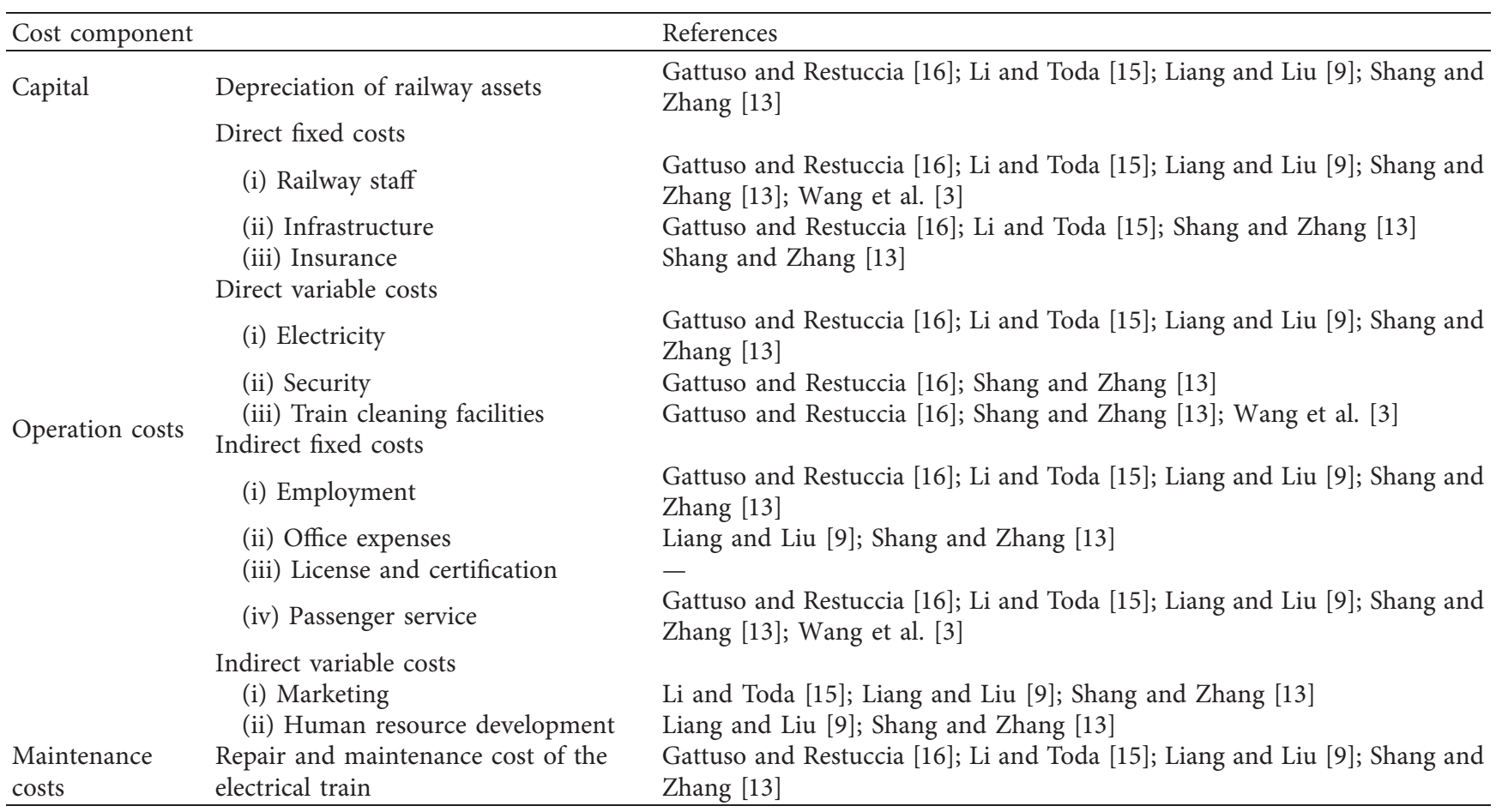

system + telecommunication system + SCADA facilities + automatic fare collection + platform screen door + substation and power distribution system + electricity + railroad + escalator and elevator $)+($ infrastructure depreciation cost $)=($ IDR 5,722,000,000+IDR 2,462,000,000+IDR 458,000, $000+$ IDR $3,655,000,000+$ IDR 4,772,000,000+IDR $3,819,000,000+$ IDR 4,507,000,000+IDR 17,105,000, $000+$ IDR $981,000,000)+(\operatorname{IDR} 133,993,000,000)=$ IDR 177,479 million/year.

Insurance costs: IDR 1,234,613.2 $\times 1 \%=$ IDR 12,346.132 million/year.

Direct variable cost $=$ electricity cost + security cost + train cleaning facilities cost.

Electricity cost: $25 \mathrm{KWh} / \mathrm{km} \times 1,025 \quad \mathrm{IDR} / \mathrm{KWh} \times$ $1,868,800 \mathrm{~km} /$ year $=$ IDR 47,720 million/year.

Security cost: IDR $5,151,693$ monthly salary $\times 32$ staff $\times 12$ month $=$ IDR 1,978 million/year.

Train cleaning facilities cost: IDR 4,112,193 monthly salary $\times 15$ staff $\times 12$ month $=$ IDR 740.19 million/year. Indirect fixed cost $=$ employment cost + office expense cost + license and certification + passenger service cost.

Employment cost: salary of director + head of division + head of department + specialist $=($ IDR 85 , $753,000,000$ monthly salary $\times 3$ staff $\times 14$ month $)+$ (IDR $42,876,000,000$ monthly salary $\times 10$ staff $\times 14$ month $)+($ IDR $30,626,000,000$ monthly salary $\times 16$ staff $\times 14$ month $)+($ IDR $11,025,000,000$ monthly salary $\times 175$ staff $\times 14$ month $)=$ IDR $3,601,600,000+$ IDR $6,002,700,000+$ IDR $\quad 6,860,200,000+$ IDR $\quad 27,012$, $100,000=$ IDR 43,476.7 million/year.
Office expense cost: IDR $1,000,000 \times 204$ staff $=I D R$ 204 million/year.

License and certification: (46 staff $\times$ IDR 1,000,000)/4 year $=$ IDR 11.5 million.

Passenger service cost: salary of security + station staff + head of station $=($ IDR 5,150,000 $\times 104$ staff $\times 12$ month $)+($ IDR $4,900,000 \times 156$ staff $\times 14$ month $)-$ $+($ IDR $18,370,000 \times 13$ staff $\times 14$ month $)=$ IDR $6,429,300,000+$ IDR 10,701,900,000 + IDR 3,344, $300,000=$ IDR 20,475.6 million/year.

Indirect variable cost $=$ marketing cost + human resource development cost.

Marketing cost: IDR $100,000,000 \times 13$ staff $\times 12$ month $=$ IDR 15,600 million/year.

Human development cost: IDR 10,000,000 $\times 201$ staff $=$ IDR 2,010 million/year.

Maintenance cost $=$ repair and maintenance cost of the electrical train $=$ IDR $8,214,360,000,000 / 30$ year $=I D R$ 273,812 million/year.

2.3. Stage 3: Comparison of the Jakarta MRT Operation and Maintenance Costs per Kilometer per Year with Other Operators. In a final step, the results of the calculations were compared to the same calculations using data taken from the annual reports of other MRT operators. For a more detailed analysis and comparison, two operators from developing countries were selected with relatively similar country conditions to Indonesia (Jakarta MRT), namely, Bangkok MRT and Delhi Metro (shown in Table 3). 
TABLE 3: Operation and maintenance cost per kilometer per year comparison (in USD).

\begin{tabular}{|c|c|c|c|c|}
\hline Cost component & & Jakarta & Bangkok & Delhi \\
\hline Depreciation of railway assets & & $5,669,973$ & $2,950,361$ & 985,709 \\
\hline Direct fixed costs & & 892,720 & 874,925 & 425,347 \\
\hline Direct variable costs & & 235,167 & 130,022 & 412,621 \\
\hline Indirect fixed costs & & 285,177 & 121,398 & 28,776 \\
\hline Indirect variable costs & & 82,108 & 28,983 & 12,597 \\
\hline \multirow{3}{*}{ Maintenance } & Total operation cost & $7,165,145$ & $4,105,689$ & $1,865,050$ \\
\hline & & $1,276,648$ & 29,275 & 50,704 \\
\hline & Total operation and maintenance cost & $8,441,793$ & $4,134,965$ & $1,915,754$ \\
\hline
\end{tabular}

\section{Results and Discussion}

The details of the operation and maintenance cost calculation results for Jakarta's MRT can be seen in Table 4 . Overall, the composition of the components is 67 percent capital cost, 18 percent operation cost (14 percent direct cost and 4 percent indirect cost), and 15 percent maintenance cost. Based on the calculation results, Jakarta's MRT operation and maintenance cost per year is USD 8.44 million per kilometer per year.

The results of the OM Jakarta MRT calculation compared with two operators in developing countries compared to Indonesia are shown in Table 3.

The data presented in Table 3 illustrate comparison of the operation and maintenance costs (OM costs) per kilometer per year of the Jakarta MRT with the Bangkok MRT and Delhi Metro using secondary data taken from each MRT operator's annual report (Bangkok MRT Annual Report 2016 and Delhi Metro Annual Report 2015). The comparison has several weaknesses, such as the expenditure details provided in the annual report which are different for each MRT operator and different conditions in each city, such as economy and policy.

Overall, the comparison shows that Jakarta MRT's OM cost is two times higher than Bangkok MRT and more than four times higher than Delhi Metro. This can be seen from the difference in the initial year of operation. The Delhi Metro began operations in 2002 and the Bangkok MRT began in 2004, while the Jakarta MRT began in 2019. The second reason was that the Jakarta MRT cooperates with JICA. As a consequence, most of the assets, machinery, and rolling stock were purchased from Japanese companies whose prices were higher due to the quality of Japan's products. The third reason is that the calculation of depreciation of railway assets for Jakarta MRT refers to government regulations in Indonesia for 30 years and might differ in Bangkok and Delhi.

\section{Summary of Findings}

This study differs from other studies on MRT costs because it produces an operation and maintenance cost model. The development of model refers to previous researches. The model can be used to calculate operation and maintenance cost per kilometer per year. This could be used as a reference in determining fares of MRT.

The model encompassed three components, namely, capital, operation costs, and maintenance costs. This OM
TABLE 4: Jakarta MRT operation and maintenance cost details.

\begin{tabular}{|c|c|c|c|}
\hline $\begin{array}{l}\text { Operation and } \\
\text { maintenance cost } \\
\text { component }\end{array}$ & $\begin{array}{c}\text { Cost per } \\
\text { unit } \times(\text { million } \\
\text { IDR }) \\
\end{array}$ & Volume & $\begin{array}{c}\text { Cost/year } \\
\text { (million } \\
\text { IDR) }\end{array}$ \\
\hline \multicolumn{4}{|l|}{ Capital } \\
\hline $\begin{array}{l}\text { Depreciation } \\
\text { of railway }\end{array}$ & & & $1,216,093$ \\
\hline & & Total capital & $1,216,093$ \\
\hline \multicolumn{4}{|l|}{ Operation costs } \\
\hline $\begin{array}{l}\text { Direct fixed } \\
\text { costs }\end{array}$ & & & 191,468 \\
\hline $\begin{array}{l}\text { Direct variable } \\
\text { costs }\end{array}$ & & & 50,438 \\
\hline $\begin{array}{l}\text { Indirect fixed } \\
\text { costs }\end{array}$ & & & 61,164 \\
\hline \multirow[t]{2}{*}{$\begin{array}{l}\text { Indirect } \\
\text { variable costs }\end{array}$} & & & 17,610 \\
\hline & & $\begin{array}{c}\text { Total } \\
\text { operation cost }\end{array}$ & $1,536,773$ \\
\hline \multirow[t]{2}{*}{$\begin{array}{l}\text { Rolling stock } \\
\text { maintenance } \\
\text { and repair }\end{array}$} & $\begin{array}{c}\text { Life cycle } \\
\text { cost }=8,214,360\end{array}$ & $\begin{array}{c}\text { Economic year } \\
30 \text { years }\end{array}$ & 273,812 \\
\hline & & $\begin{array}{c}\text { Total } \\
\text { maintenance } \\
\text { cost }\end{array}$ & 273,812 \\
\hline $\begin{array}{l}\text { Operation and } \\
\text { maintenance cost } \\
\text { per year }\end{array}$ & & & $1,810,585$ \\
\hline $\begin{array}{l}\text { Operation and } \\
\text { maintenance cost } \\
\text { per km per year }\end{array}$ & & 16 kilometers & 113,161 \\
\hline
\end{tabular}

cost model can be used as a reference calculation for other countries or operators with conditions similar to those of Jakarta MRT.

The OM cost for Jakarta MRT is USD 8.44 million per kilometer. The composition of the components is 67 percent capital cost, 18 percent operation cost (14 percent direct cost and 4 percent indirect cost), and 15 percent maintenance cost. The comparison results between Jakarta MRT, Bangkok MRT, and Delhi Metro show that OM cost of Jakarta MRT is higher than that of Bangkok MRT and Delhi Metro.

The practical applicability of the model could be used to determine fares, marketing, and salary adjustments, and unreasonable costs can be identified, evaluated, and addressed. Similar calculations can be made for other 
systems; however, MRT operation and maintenance cost components need to be modeled based on regulations and conditions in the respective country and region to obtain valid calculations.

\section{Future Research}

The calculation results in this study could be compared with the actual condition of the Jakarta MRT. Another future research of this study is the ticket prices calculation by considering cost recovery ratio and profit for operators. The calculation of ticket prices could also consider willingness to pay from passengers so that government subsidies can be calculated.

\section{Data Availability}

The data used to support the findings of this study are available from the corresponding author upon request.

\section{Conflicts of Interest}

The authors declare that there are no conflicts of interest regarding the publication of this paper.

\section{Acknowledgments}

This work was financially supported by the HIBAH PITTA Q1Q2 under Contract no. NKB-0320/UN2.R3.1/HKP.05.00/ 2019.

\section{References}

[1] Sugiarto, T. Miwa, H. Sato, and T. Morikawa, "Transportation expenditure frontier models in Jakarta metropolitan area," Procedia-Social and Behavioral Sciences, vol. 138, pp. 148158, 2014.

[2] S. Soehodho, "Public transportation development and traffic accident prevention in Indonesia," IATSS Research, vol. 40, no. 2, pp. 76-80, 2017.

[3] R. Wang, M. Kudrot-E-Khuda, F. Nakamura, and S. Tanaka, "A cost-benefit analysis of commuter train improvement in the Dhaka Metropolitan Area, Bangladesh," Procedia-Social and Behavioral Sciences, vol. 138, pp. 819-829, 2014.

[4] P. Kaewwongwattana, V. Panjakajornsak, and P. Pimdee, "Bangkok's mass rapid transit system's commuter decisionmaking process in using integrated smartcards," Kasetsart Journal of Social Sciences, vol. 37, no. 2, pp. 112-118, 2016.

[5] J. Zhang and H. Yang, "Transit operations with deterministic optimal fare and frequency control," Transportation Research Procedia, vol. 14, pp. 313-322, 2016.

[6] B. Pusat, Statistik Daerah Khusus Ibukota. Transportation Statistic of DKI Jakarta, BPS DKI, Central Jakarta, Indonesia, 2017.

[7] M. R. T. Jakarta, "Proyek dan perkembangan [project and development] Jakarta," 2017, https://www.jakartamrt.co.id/ proyek-dan-perkembangan/.

[8] V. R. Vuchic, Transportation Engineering and Planning, EOLSS Publisher/UNESCO, Oxford, UK, 2009.

[9] J. Liang and Z. Liu, "Analysis of urban rail transit operation cost control," International Journal of Business and Social Science, vol. 5, no. 5, pp. 140-142, 2014.
[10] D. Bruckmann, A. Bomhauer-Beins, and U. Weidmann, "A qualitative model to evaluate the financial effects of innovations in the rail sector," Transportation Research Procedia, vol. 10, pp. 564-573, 2015.

[11] American Public Transit Association, Glossary of Transit Terminology, American Public Transit Association, Washington DC, USA, 1994.

[12] Y. Zhu and M. Diao, "The impacts of urban mass rapid transit lines on the density and mobility of high-income households: a case study of Singapore," Transport Policy, vol. 51, pp. 70-80, 2016.

[13] B. Shang and X. Zhang, "Study of urban rail transit operation costs," Procedia-Social and Behavioral Sciences, vol. 96, pp. 565-573, 2013.

[14] L. Kirkwood, E. Shehab, P. Baguley, and A. Starr, "Uncertainty of net present value calculations and the impact on applying integrated maintenance approaches to the UK rail industry," Procedia CIRP, vol. 38, pp. 245-249, 2015.

[15] G. Li and C. Toda, "Discussions on the local rail transit system in the urbanization," Procedia-Social and Behavioral Sciences, vol. 138, pp. 193-198, 2014.

[16] D. Gattuso and A. Restuccia, "A tool for railway transport cost evaluation," Procedia-Social and Behavioral Sciences, vol. 111, pp. 549-558, 2014.

[17] F. Calvo and J. De Oña, "Are rail charges connected to costs?" Journal of Transport Geography, vol. 22, pp. 28-33, 2012.

[18] Kementrian Perhubungan Indonesia, Guidance on Calculation and Determination of Railway Tariff, T. Mo, Ed., Kementrian Perhubungan Indonesia, Jakarta, Indonesia, 2014.

[19] R. A. Brealey, S. C. Myers, and A. J. Marcus, Fundamentals of Corporate Finance, McGraw-Hill/Irwin, New York, NY, USA, 6th edition, 2012. 